九州大学学術情報リポジトリ

Kyushu University Institutional Repository

\title{
Studies on the Evaluation of Dowel-Bearing Strength for the Manufacture of Skin Timber
}

\section{Kim, Gwang-Chul}

Department of Housing environmental design, College of Human Ecology, Chonbuk National University

\section{Kang, Chun-Won}

Department of Housing environmental design, College of Human Ecology, Chonbuk National University

Matsumura, Junj i

Laboratory of Wood Science, Department of Forest and Forest Product Science, Faculty of Agriculture, Kyushu University

https://doi.org/10.5109/16129

出版情報: 九州大学大学院農学研究院紀要. 54 (2)，pp.449-455，2009-10-29. Faculty of Agriculture, Kyushu University

バージョン：

権利関係 : 


\title{
Studies on the Evaluation of Dowel-Bearing Strength for the Manufacture of Skin Timber
}

\author{
Gwang-Chul KIM*1, Chun-Won KANG ${ }^{1}$ and Junji MATSUMURA ${ }^{2}$ \\ Laboratory of Wood Science, Department of Forest and Forest Product Science, \\ Faculty of Agriculture, Kyushu University, Fukuoka 812-8581, Japan \\ (Received June 30, 2009 and accepted July 13, 2009)
}

\begin{abstract}
Korean prefers the post-and-beam construction with exposed very large-scale structural members to building with light wood frames, as with the 2-by-4 method of construction and pre-fabricated methods. One potential solution is the use of skin timbers. In this study, we performed experiments on with non-bored and bored small clear samples in order to determine the bearing strength of the bored specimens compared with the non-bored specimens and to determine the difference in performance between them as a function of the load direction. This study showed that when the clear small specimens were bored, their bearing strength was considerably reduced and there was a large difference in bearing strength between the parallel and perpendicular load directions. We conclude that additional research with full-sized Skin Timber is required.
\end{abstract}

Keywords: Skin timber, structural member, post and beam construction, bored, non-bored

\section{INTRODUCTION}

A skin timber is a type of wooden structural member that is circular or square in cross section and that has an inner hole that is approximately 90\% the width of the external measurement. It can be the best choice for building large-scale wooden structures of the sort that have been in increasing demand in Korea recently.

In the United States and Canada, single-family houses and some apartment houses are generally of a woodframe construction. According to a survey (KFRI, 2007), however, Korean people tend to prefer the post-andbeam type of house with exposed structural members because of the sentimental appeal of traditional Koreanstyle houses. According to the report, 'The research on the future of Korean-style wooden building,' conducted by the Korea Forest Research Institute (2007), both suppliers and consumers (63.3\% of suppliers and $98.3 \%$ of consumers) prefer the post-and-beam construction with exposed very large-scale structural members to building with light wood frames, as with the 2-by-4 method of construction and pre-fabricated methods. One potential solution is the use of skin timbers.

The structural members used in the post-and-beam method of construction are required to have high structural performance of connection. It is the bearing strength of the members that determines the structural performance of connection. Therefore, in this study, we performed experiments on with non-bored and bored small clear samples in order to determine the bearing strength of the bored specimens compared with the non-bored specimens and to determine the difference in

\footnotetext{
1 Department of Housing environmental design, College of Human Ecology, Chonbuk National University, Jeonju 561-756, Korea

2 Laboratory of Wood Science, Department of Forest and Forest Product Science, Faculty of Agriculture, Kyushu University, Fukuoka 812-8581, Japan

* Corresponding author (E-mail: gckim@chonbuk.ac.kr)
}

performance between them as a function of the load direction. Once large-scale skin timber is made, a similar evaluation of bearing strength should be carried out on the full-size samples. We are developing the skin timber such as Fig. 1.
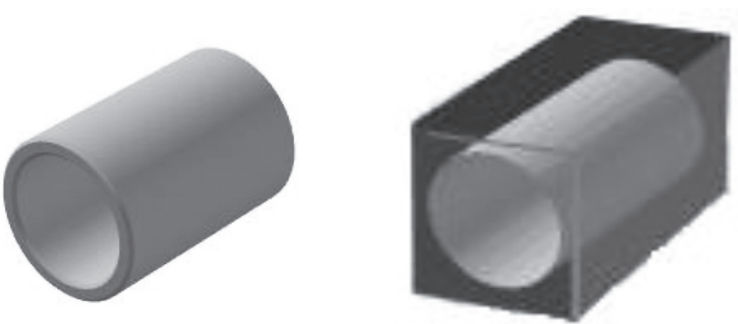

Fig. 1. Skin timber configuration.

\section{MATERIALS AND METHODS}

In this study we tested pine and larch, which are widely used in Korea as structural members. All specimens were $20 \mathrm{~mm} \times 20 \mathrm{~mm} \times 30 \mathrm{~mm}$. They were made in accordance with KSF 2206-2004-06. For both pine and larch, we prepared solid (non-bored) and hollow (bored with a 10-mm hole) samples and conducted tests of load-bearing strength. We tested with the load both parallel to the grain and perpendicular to the grain. In the tests, a steel rod with $10 \mathrm{~mm}$ diameter was used. The testing machine was an R\&B model Unitech $\mathrm{S}^{\mathrm{TM}}$, which has a maximum load capacity of 10 tons.

\section{RESULTS AND DISCUSSION}

\section{Load-deformation curves for the two load direc- tions}

Most of the load-deformation curves for the nonbored specimens with the load parallel to the grain were similar to Figure 2.

Most of the load-deformation curves for the bored 
specimens with the load parallel to the grain were similar to Figure 3.

As we can see from Figures 2 and 3, when compared with the non-bored sample, the bored sample with the 10-mm hole had the ability to continue deforming to a certain extent after the load reached a peak.

The cross-sectional area of the bored specimen (with a $10-\mathrm{mm}$ hole) is about $80 \%$ of the cross-sectional areas of the $20 \mathrm{~mm}-$ by-20 mm non-bored sample. The structural performance of this member was considerable because the specimen has a substantial residual area. In case of pine, the residual strength of bored specimen was $76 \%$ of the strength of the non-bored specimen, and

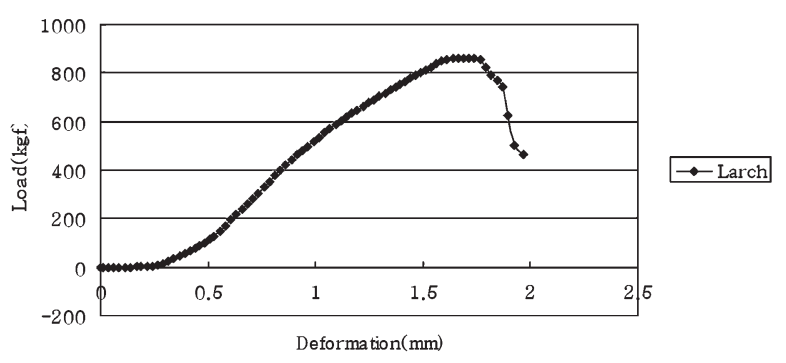

Fig. 2. Load-deformation curve of non-bored specimen for load parallel to grain. (Non-bored, larch II -No. 4) (II: parallel) $^{-10}$

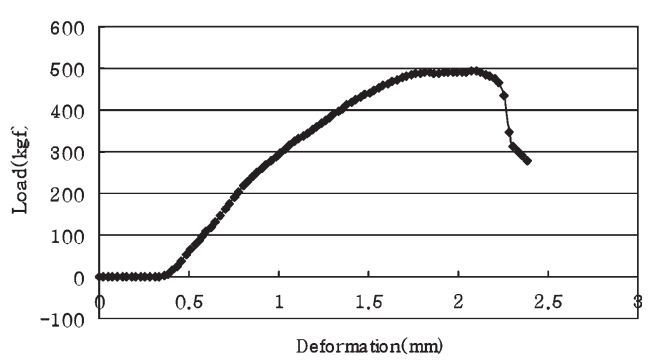

$\rightarrow$ Larch

Fig. 3. Load-deformation curve of bored specimen for load parallel to the grain. (Bored, larch $\|-$ No.2) (ll: parallel) $^{-10}$ the residual strength of the larch was $90 \%$.

In terms of the bearing strength, however, the residual strength of the bored specimen was $60 \%$ for larch and $62 \%$ for pine. (Table 1.) It is clear that the residual capacity of bearing strength was greatly reduced in comparison with the structural residual capacity. In other words, it will be important to take the substantial reduction in bearing strength into account to manufacture a connection.

Most of the load-deformation curves of the nonbored specimens with load perpendicular to the grain were similar to Figure 4.

Most of the load-deformation curves of the bored

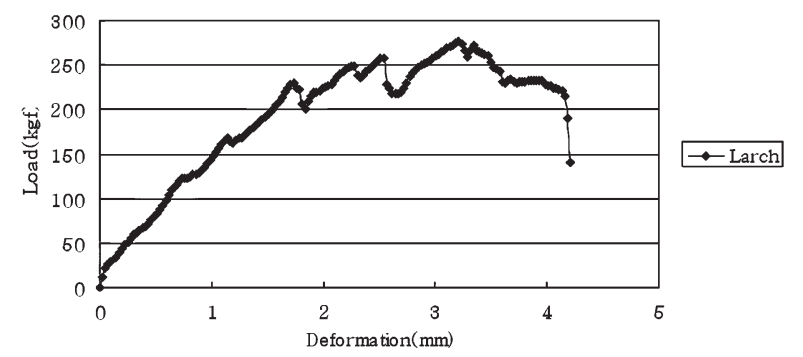

Fig. 4. Load-deformation curves of non-bored specimen for load perpendicular to the grain. (Non-bored, larch $\perp-$ No. 9) ( $($ : perpendicular)

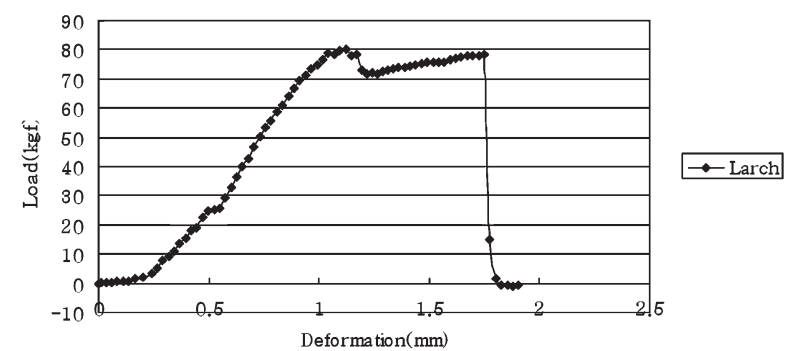

Fig. 5. Load-deformation curves of bored specimens for load perpendicular to the grain. (Bored, larch $\perp-$ No. 6) ${ }^{(\perp \text { : perpendicular })}$

Table 1. Test results for the determination of bearing strength (MPa)

\begin{tabular}{|c|c|c|c|c|c|}
\hline \multirow[t]{2}{*}{ Pine } & \multicolumn{5}{|c|}{ Larch } \\
\hline & Parallel & Perpendicular & & Parallel & Perpendicular \\
\hline \multirow{5}{*}{$\begin{array}{l}\text { Non- } \\
\text { bored }\end{array}$} & 29.98 & 15.01 & \multirow{5}{*}{$\begin{array}{l}\text { Non- } \\
\text { bored }\end{array}$} & 42.4 & 7.36 \\
\hline & 36.81 & 13.27 & & 41.33 & 10.00 \\
\hline & 27.11 & 13.96 & & 46.72 & 10.83 \\
\hline & 26.75 & 11.17 & & 42.23 & 9.04 \\
\hline & 26.38 & 10 & & 39.34 & 13.65 \\
\hline Average & 29.41 & 12.68 & Average & 42.41 & 10.18 \\
\hline \multirow{5}{*}{$\begin{array}{l}10 \mathrm{~mm} \\
\text { bored }\end{array}$} & 16.82 & 3.13 & \multirow{5}{*}{$\begin{array}{l}10 \mathrm{~mm} \\
\text { bored }\end{array}$} & 24.84 & 2.61 \\
\hline & 22.86 & 2.31 & & 24.14 & 2.45 \\
\hline & 21.16 & 2.45 & & 30.68 & 2.86 \\
\hline & 12.98 & 2.94 & & 23.18 & 2.39 \\
\hline & 17.43 & 2.13 & & 24.46 & 2.34 \\
\hline Average & 18.25 & 2.59 & Average & 25.46 & 2.53 \\
\hline
\end{tabular}


specimens with load perpendicular to the grain were similar to Figure 5.

When specimens were given a load perpendicular to the grain, deformation continued to some extent after the load reached a peak. However, it would be unreasonable to consider this as the bearing strength capacity because the structural performance of wood tissue was defective. For bored specimens, the residual bearing strength was $20 \%$ in pine and $25 \%$ in larch (Table 1.). When the load direction was perpendicular to grain, the reduction in capacity was substantial compared to when the load was parallel to grain. Therefore, it will be necessary to design and construct connections carefully so as to avoid them being loaded perpendicular to grain as much as possible; when such loading is inevitable, adequate reinforcement should be required.

\section{Comparison between the estimated value and the tested value}

The Korean Building Code prescribes certain bearing-strength values according to the load direction and the specific gravity of the material. The formulae are as follows:

$$
\begin{aligned}
& F_{e \mathbb{I}}=79 G(M P a) \quad \text { (load direction is parallel to grain) } \\
& F_{e \perp}=\frac{216 G^{1.45}}{\sqrt{D}}(M P a)
\end{aligned}
$$

(load direction is perpendicular to grain)

$$
F_{e \theta}=\frac{F_{e \mathbb{I}} F_{e \perp}}{F_{e \mathbb{I}} \sin ^{2} \theta+F_{e \perp} \operatorname{con}^{2} \theta}
$$

(load direction is optional to grain)

According to the formulae, when the load direction is parallel to the grain, the value for pine is $35.55 \mathrm{MPa}$, assuming a specific gravity for pine of 0.45 , on the $\mathrm{KBC}$ (Korean Building Code). When the load direction is perpendicular to grain, the value is $21.46 \mathrm{MPa}$. Similarly, the values of Larch are $39.5 \mathrm{MPa}$ and $25.02 \mathrm{MPa}$, assuming a specific gravity of 0.50 .

Table 1 shows the bearing-strength values for pine and larch according to the load direction.

As shown in detail in Figure 6, when the load direction was parallel to the grain, the tested values were similar to the estimated values. By contrast, the tested values were smaller than the estimated values when the

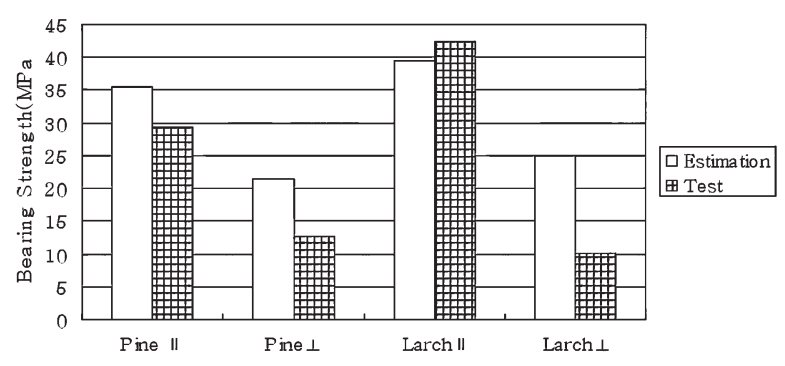

Fig. 6. Comparison between estimated values and tested values for each non-bearing specimen. (II: parallel, $\perp$ : perpendicular) loading was perpendicular to the grain. It is well known that when a timber is loaded perpendicular to grain, its structural performance becomes considerably weaker, so caution is needed in construction. In this situation, the reduction in the structural performance of the bored specimens was substantial, and we conclude that building with full-size skin timber will require that the structural performance of the timber be reinforced by the hybrid structure.

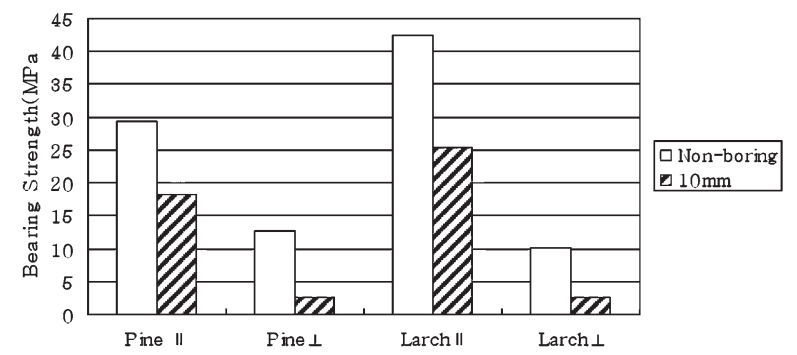

Fig. 7. Comparison between non-bored specimens and bored specimens for the two species. (II:parallel, $\perp$ : perpendicular)

As can be seen in Figure 7, the difference in bearing strength between the tested values loaded parallel to the grain and perpendicular to the grain was considerable, which is well known.

When the specimens were loaded parallel to the grain, the bored larch and pine had $60 \%$ and $62 \%$ of the residual strength compared with the non-bored larch and pine. (See Table 1.) Also, when loaded perpendicular to the grain, the residual bearing strength of the bored larch and pine were $20 \%$ and $25 \%$. (See Table 1.) From this it could be seen that the bearing strength when loaded perpendicular to the grain is greatly reduced compared with the parallel load direction.

For non-bored specimens, the ratio of the perpendicular bearing strength to the parallel bearing strength was $43 \%$ for pine and $24 \%$ for larch. For the bored specimens, the corresponding values were $14 \%$ for pine and $10 \%$ for larch (See Table 1.). Examining the pictures in Figure 8, one can easily see these differences. The upper

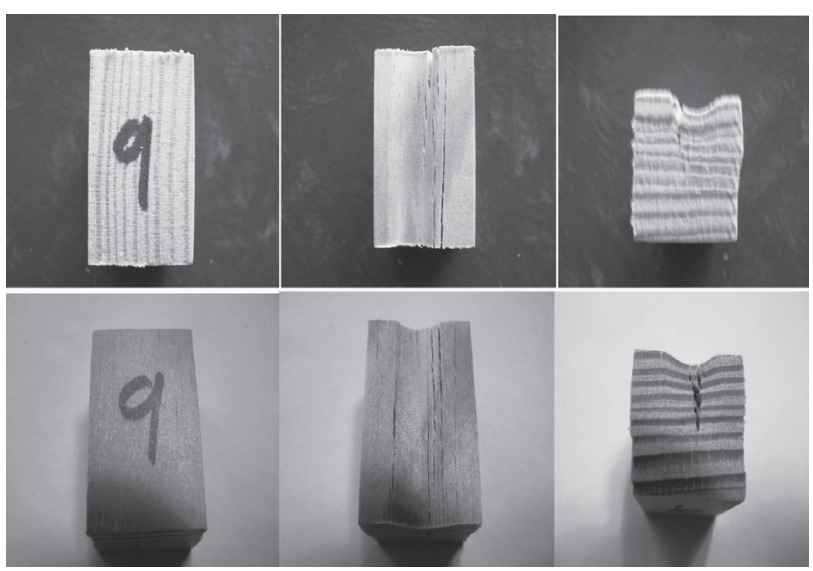

Fig. 8. Failure features for the load perpendicular to the grain. (Top: pine, bottom: larch) 
picture is of pine in a strength test with the load perpendicular to the grain, the lower picture is of the larch. When the specimens were loaded perpendicular to the grain, the larch had less bearing strength than the pine because the tearing in the tissue of the larch was more severe.

As described above, the main focus of this study was to investigate how much reduction in bearing strength should be anticipated in fasteners. In the beginning, we did not expect that the bearing strength would be reduced substantially because a $10-\mathrm{mm}$ hole bored in this sample removed only $20 \%$ from the cross section of the nonbored specimen in terms of area. In other words, the residual area was still quite substantial. However, as can be seen from Table 1, the reduction in bearing strength was considerable, which will have an influence on the performance of fasteners. Therefore, we concluded that future research should focus on hybrid structures, which boost the bearing strength.

The significance of differences in bearing strength between bored specimens and non-bored specimens

From Table 1 it is evident that there are differences in the average value of the bearing strength between non-bored and bored specimens. However, we needed to perform a statistical analysis in order to determine whether the results were statistically significant or not.

Table 2. F-test result and t-test result in the case of pine loaded parallel to the grain

F-test: two sample for variance (Pine $\|$ )

\begin{tabular}{ccc}
\hline & Variable 1 & Variable 2 \\
\hline Mean & 29.40706 & 18.25093 \\
Variance & 19.17119 & 15.05632 \\
Observations & 5 & 5 \\
df & 4 & 4 \\
F & 1.273298 & \\
P (F<=f) one-tail & 0.410269 & \\
F critical: one-tail & 6.388233 & \\
\hline
\end{tabular}

\begin{tabular}{ccc}
\multicolumn{3}{c}{ t-test: assuming equal variances } \\
\hline Mean & Variable 1 & Variable 2 \\
Variance & 29.40706 & 18.25093 \\
Observations & 19.17119 & 15.05632 \\
Pooled variance & 5 & 5 \\
Hypothesized & 17.11376 & \\
Mean difference & 0 & \\
df & 8 & \\
t value & 4.263936 & \\
P $(\mathrm{T}<=$ t) one-tail & 0.001373 & \\
t critical one-tail & 1.859548 & \\
P $(\mathrm{T}<=$ t) two-tail & 0.002747 & \\
t critical two-tail & 2.306004 &
\end{tabular}

We first applied F-test to check that both groups had the same variance. When the $\mathrm{p}$-value was less than 0.05 , we conducted a t-test assuming different variance and when the t-value was more than 0.05 , we conducted a t-test assuming equal variance. The significance tests were conducted in with the parallel and perpendicular to the grain for each species.

In the case of pine loaded parallel to the grain, a t-test assuming equal variance was conducted because the $\mathrm{p}$-value of the F-test was 0.41 . The result is the Table 2. The t-test found a p-value of less than 0.01 , which meant that the two groups had a statistically significant difference in strength within both a 95\% and a 99\% confidence interval. This statistically significant difference in bearing strength between the bored and the non-bored groups indicates that care should be taken in the design and construction of connections.

Similarly, for pine loaded perpendicular to the grain, a t-test assuming different variance was conducted because the $\mathrm{p}$-value of the F-test was 0.004 in Table 3 . The $t$-test found the $\mathrm{p}$-value to be more than 0.05 . This means that there is no difference between the two groups with a $95 \%$ confidence interval. In other words, although the bearing strength of the bored group is considerably less than that of the non-bored group, the differences in bearing strength between the two groups are not statistically significant. When the members are loaded perpendicular to grain, however, their bearing strength is

Table 3. F-test result and t-test result in the case of pine loaded perpendicular to the grain

F-test: two sample for variance $($ Pine $\perp$ )

\begin{tabular}{ccc}
\hline & Variable 1 & Variable 2 \\
\hline Mean & 12.68015 & 2.590467 \\
Variance & 4.217306 & 0.180698 \\
Observations & 5 & 5 \\
df & 4 & 4 \\
F & 23.33894 & \\
P (F<=f) one-tail & 0.004926 & \\
F critical: one-tail & 6.388233 & \\
\hline
\end{tabular}

t-test: assuming unequal variances

\begin{tabular}{ccc}
\multicolumn{3}{c}{ t-test: assuming unequal variances } \\
\hline Mean & Variable 1 & Variable 2 \\
Variance & 12.68015 & 2.590467 \\
Observations & 4.217306 & 0.180698 \\
Pooled variance & 5 & 5 \\
Hypothesized & 0 & \\
Mean difference & 4 & \\
df & 10.75808 & \\
t value & 0.000212 & \\
P $(\mathrm{T}<=$ t) one-tail & 2.131847 & \\
$\mathrm{t}$ critical one-tail & 0.000423 & \\
$\mathrm{P}(\mathrm{T}<=\mathrm{t})$ two-tail & 2.776445 & \\
\hline
\end{tabular}


Table 4. F-test result and t-test result in the case of larch loaded parallel to the grain

F-test: two sample for variance (Larch || )

\begin{tabular}{ccc}
\hline & Variable 1 & Variable 2 \\
\hline Mean & 42.40548 & 25.46128 \\
Variance & 7.305625 & 8.894356 \\
Observations & 5 & 5 \\
df & 4 & 4 \\
F & 0.821378 & \\
P (F $<=$ f) one-tail & 0.426683 & \\
F critical: one-tail & 0.156538 & \\
\hline
\end{tabular}

t-test: assuming equal variances

\begin{tabular}{|c|c|c|}
\hline & Variable 1 & Variable 2 \\
\hline Mean & 42.40548 & 25.46128 \\
\hline Variance & 7.305625 & 8.894356 \\
\hline Observations & 5 & 5 \\
\hline Pooled variance & 8.09999 & \\
\hline $\begin{array}{l}\text { Hypothesized } \\
\text { Mean difference }\end{array}$ & 0 & \\
\hline df & 8 & \\
\hline $\mathrm{t}$ value & 9.41345 & \\
\hline $\mathrm{P}(\mathrm{T}<=\mathrm{t})$ one-tail & $6.65 \mathrm{E}-06$ & \\
\hline t critical one-tail & 1.859548 & \\
\hline $\mathrm{P}(\mathrm{T}<=\mathrm{t})$ two-tail & $1.33 \mathrm{E}-05$ & \\
\hline t critical two-tail & 2.306004 & \\
\hline
\end{tabular}

reduced substantially. Therefore, it will be necessary to design and construct connections carefully so as to avoid loading perpendicular to the grain as much as possible and, when such loading is unavoidable, to provide sufficient reinforcement.

In case of larch loaded parallel to the grain, a t-test assuming equal variance was conducted because the p-value of the F-test was 0.42 in Table 4 . The t-test showed a p-value of $1.33 \mathrm{E}-05$, which implied that the difference between the two groups was statistically significant at not only the $95 \%$ but also the $99 \%$ confidence interval. Just as with pine, the significant differences in bearing strength between bored and non-bored larch should be considered in the design and construction of connections.

For larch loaded perpendicular to the grain, a t-test assuming different variance was conducted because the p-value of the F-test was 0.0002 in Table 5. The t-test showed a $\mathrm{p}$-value of more than 0.05 . This indicates that there is no statistically significant difference between the two groups within the $95 \%$ confidence interval. As with pine, although there is no significant difference between the two groups, it will still be necessary to design and construct the connections so as to avoid loads perpendicular to the grain.
Table 5. F-test result and t-test result in the case of larch loaded perpendicular to the grain

F-test: two sample for variance (Larch $\perp$ )

\begin{tabular}{ccc}
\hline & Variable 1 & Variable 2 \\
\hline Mean & 10.17717 & 2.530621 \\
Variance & 5.429789 & 0.043631 \\
Observations & 5 & 5 \\
df & 4 & 4 \\
F & 124.4472 & \\
P (F<=f) one-tail & 0.00019 & \\
F critical: one-tail & 6.388233 & \\
\hline
\end{tabular}

\begin{tabular}{ccc}
\multicolumn{3}{c}{ t-test: assuming unequal variances } \\
\hline Mean & Variable 1 & Variable 2 \\
Variance & 10.17717 & 2.530621 \\
Observations & 5.429789 & 0.043631 \\
Pooled variance & 5 & 5 \\
Hypothesized & 0 & \\
Mean difference & 4 & \\
df & 7.308379 & \\
t value & 0.000932 & \\
$\mathrm{P}(\mathrm{T}<=\mathrm{t})$ one-tail & 2.131847 & \\
$\mathrm{t}$ critical one-tail & 0.001864 & \\
$\mathrm{P}(\mathrm{T}<=\mathrm{t})$ two-tail & 2.776445 &
\end{tabular}

\section{The significance test of bearing strength for the load directions}

We first determined that the relationship between the two groups was an equal variance or different variance and then conducted a t-test. For both load directions, the significance test was conducted for bored and non-bored specimens of the two species. In the case of the non-bored pine, a t-test assuming equal variance was conducted because the p-value of the $\mathrm{F}$-test was 0.09 in Table 6. The t-test led to a p-value much less than 0.01, which meant that for the two groups the difference between the load directions was highly significant. That is, the difference in bearing strength was significant not only at 95\% confidence but also at 99\% confidence. Again, it will be necessary to design and construct connections so as to avoid loads perpendicular to the grain.

In the case of bored pine, a t-test assuming different variance was conducted because the $p$-value of the F-test was less than 0.05 in Table 7 . The t-test led to a p-value of more than 0.05 . This indicates that the difference between the load directions was not significant for the two groups. It is clear that studies on full-size Skin Timber will be required, given the results from the small clear specimens in this study. That is, even though the specimens were bored so that $80 \%$ of the original area still remained, the bearing strength was considera- 
Table 6. F-test result and t-test result in the case of non-bored pine

F-test: two sample for variance (Pine, non-bored)

\begin{tabular}{ccc}
\hline & Variable 1 & Variable 2 \\
\hline Mean & 29.40706 & 12.68015 \\
Variance & 19.17119 & 4.217306 \\
Observations & 5 & 5 \\
df & 4 & 4 \\
F & 4.545839 & \\
P (F<=f) one-tail & 0.085815 & \\
F critical: one-tail & 6.388233 & \\
\hline
\end{tabular}

\begin{tabular}{ccc}
\multicolumn{3}{c}{ t-test: assuming equal variances } \\
\hline Mean & Variable 1 & Variable 2 \\
Variance & 29.40706 & 12.68015 \\
Observations & 19.17119 & 4.217306 \\
Pooled variance & 5 & 5 \\
Hypothesized & 11.69425 & \\
Mean difference & 0 & \\
df & 8 & \\
t value & 7.733914 & \\
$\mathrm{P}(\mathrm{T}<=\mathrm{t})$ one-tail & $2.78 \mathrm{E}-05$ & \\
$\mathrm{t}$ critical one-tail & 1.859548 & \\
$\mathrm{P}(\mathrm{T}<=\mathrm{t})$ two-tail & $5.57 \mathrm{E}-05$ & \\
$\mathrm{t}$ critical two-tail & 2.306004 & \\
\hline
\end{tabular}

bly reduced. Therefore, we conclude that not only will the connections need reinforcement, a high-level hybrid structure for Skin Timber will need to be developed.

For the non-bored larch, a t-test assuming equal variance was conducted because the $p$-value of the F-test was 0.39 in Table 8. The t-test led to a p-value much less than 0.01 , which meant that the difference between the load directions was highly significant for the two groups. That is, a difference in bearing strength was seen not only at the $95 \%$ confidence level but also at the 99\% confidence level. Therefore, as was the case with pine, it will be necessary to design and construct connections so as to avoid loads perpendicular to grain.

In the case of the bored larch, a t-test assuming different variance was conducted because the $p$-value of the F-test was less than 0.05 in Table 9. The t-test led to a p-value of more than 0.05 . This indicates that there was no significant difference between the load directions for the two groups, which was the same result as for pine.

\section{CONCLUSION}

When the specimens were loaded parallel to the grain, the tested values were similar to the estimated values based on the KBC. By contrast, when loaded perpendicular to the grain, the samples had tested values that were
Table 7. F-test result and t-test result in the case of bored pine

\begin{tabular}{ccc}
\multicolumn{2}{c}{ F-test: two sample for variance (Pine, bored) } \\
\hline Variable 1 & Variable 2 \\
\hline Mean & 18.25093 & 2.590467 \\
Variance & 15.05632 & 0.180698 \\
Observations & 5 & 5 \\
df & 4 & 4 \\
F & 83.32302 & \\
P (F<=f) one-tail & 0.000419 & \\
F critical: one-tail & 6.388233 & \\
\hline
\end{tabular}

\begin{tabular}{|c|c|c|}
\hline & Variable 1 & Variable 2 \\
\hline Mean & 18.25093 & 2.590467 \\
\hline Variance & 15.05632 & 0.180698 \\
\hline Observations & 5 & 5 \\
\hline Pooled variance & 0 & \\
\hline $\begin{array}{l}\text { Hypothesized } \\
\text { Mean difference }\end{array}$ & 4 & \\
\hline $\mathrm{df}$ & 8.970975 & \\
\hline $\mathrm{t}$ value & 0.000427 & \\
\hline $\mathrm{P}(\mathrm{T}<=\mathrm{t})$ one-tail & 2.131847 & \\
\hline t critical one-tail & 0.000854 & \\
\hline $\mathrm{P}(\mathrm{T}<=\mathrm{t})$ two-tail & 2.776445 & \\
\hline
\end{tabular}

Table 8. F-test result and t-test result in the case of non-bored larch

F-test: two sample for variance (Larch non-bored)

\begin{tabular}{ccc}
\hline & Variable 1 & Variable 2 \\
\hline Mean & 42.40548 & 10.17717 \\
Variance & 7.305625 & 5.429789 \\
Observations & 5 & 5 \\
df & 4 & 4 \\
F & 1.345471 & \\
P (F<=f) one-tail & 0.390329 & \\
F critical: one-tail & 6.388233 & \\
\hline
\end{tabular}

\begin{tabular}{|c|c|c|}
\hline & Variable 1 & Variable 2 \\
\hline Mean & 42.40548 & 10.17717 \\
\hline Variance & 7.305625 & 5.429789 \\
\hline Observations & 5 & 5 \\
\hline Pooled variance & 6.367707 & \\
\hline $\begin{array}{l}\text { Hypothesized } \\
\text { Mean difference }\end{array}$ & 0 & \\
\hline $\mathrm{df}$ & 8 & \\
\hline $\mathrm{t}$ value & 20.19371 & \\
\hline $\mathrm{P}(\mathrm{T}<=\mathrm{t})$ one-tail & $1.89 \mathrm{E}-08$ & \\
\hline $\mathrm{t}$ critical one-tail & 1.859548 & \\
\hline $\mathrm{P}(\mathrm{T}<=\mathrm{t})$ two-tail & $3.78 \mathrm{E}-08$ & \\
\hline $\mathrm{t}$ critical two-tail & 2.306004 & \\
\hline
\end{tabular}


Table 9. F-test result and t-test result in the case of bored Larch F-test: two sample for variance (Larch, bored)

\begin{tabular}{ccc}
\hline & Variable 1 & Variable 2 \\
\hline Mean & 25.46128 & 2.530621 \\
Variance & 8.894356 & 0.043631 \\
Observations & 5 & 5 \\
df & 4 & 4 \\
F & 203.8528 & \\
P (F<=f) one-tail & $7.13 \mathrm{E}-05$ & \\
F critical: one-tail & 6.388233 & \\
\hline
\end{tabular}

t-test: assuming unequal variances

\begin{tabular}{ccc}
\multicolumn{3}{c}{ t-test: assuming unequal variances } \\
\hline Mean & Variable 1 & Variable 2 \\
\hline Variance & 25.46128 & 2.530621 \\
Observations & 8.894356 & 0.043631 \\
Pooled variance & 5 & 5 \\
Hypothesized & 0 & \\
Mean difference & 4 & \\
df & & \\
t value & 17.15069 & \\
P $(\mathrm{T}<=\mathrm{t})$ one-tail & $2.39 \mathrm{E}-05$ & \\
$\mathrm{t}$ critical one-tail & $6.78 \mathrm{E}-05$ & \\
$\mathrm{P}(\mathrm{T}<=\mathrm{t})$ two-tail & 2.776445 & \\
\hline
\end{tabular}

much less than the estimated values.

When the specimens were loaded parallel to the grain, the residual strengths of the bored larch and pine were $60 \%$ and $62 \%$ compared with the non-bored larch and pine. When loaded perpendicular to the grain, the residual bearing strengths of the bored larch and pine were $20 \%$ and $25 \%$. From this result, it can be seen that when loaded perpendicular to grain, the reduction in bearing strength is substantial compared with the reduction for the parallel load direction.

For non-bored specimens, the ratio of the perpendicular bearing strength to the parallel bearing strength was $43 \%$ for pine and $24 \%$ for larch. For the bored specimens, the value for pine was about $14 \%$ and for larch about $10 \%$.

For both pine and larch loaded parallel to the grain, the difference between the non-bored and the bored groups statistically significant within the $99 \%$ confidence interval. However, when loaded perpendicular to grain, there was no significant difference between the two groups.

For non-bored pine and larch, the difference between the load directions was statistically significant within the $99 \%$ confidence interval. By contrast, there was no significant difference between the load directions for bored specimens.

This study showed that when the clear small specimens were bored, their bearing strength was considerably reduced and there was a large difference in bearing strength between the parallel and perpendicular load directions. We conclude that additional research with full-sized Skin Timber is required.

\section{ACKOWLEDGEMENT}

This study was carried out with the support of 'Forest Science \& Technology Projects (Project No. 140201001)' provided by Korea Forest Service.

\section{REFERENCES}

An annual report of construction statistics. 2007. The Ministry of Construction and Transportation

An annual report for forestry tendency. 2007. The office of Forestry

American Institute of Timber Construction. 2004. Timber construction manual. John Wiley \& Sons Ltd

Breyer, D. E. 1993. Design of wood structures. McGraw-Hill, New York, USA

Canadian Wood Council. 1995. Wood design manual. CWC, Canada

KSF 2206-2004-06. Method of compression test for wood

Korean Building Code. 2006. Kimoondang

Madsen, B. 2000. Behavior of timber connections. Timber Engineering Ltd, Canada

Motoaki Okuma and Yoshinori Mizuta. 1982. Performance of box members of laminated veneer lumber (LVL) I -Box type posts of LVL made of larch veneers-Mokuzai Gakkaishi 28(12): 756-762

Motoaki Okuma and Takashi Takeda 1989. Properties and application of laminated-veneer lumber posts with hollow cores II -Shearing properties of wall frameworks made of laminated- veneer lumber posts with hollow cores and long bolts-Mokuzai Gakkaishi 35 (11): 972-977

Motoaki Okuma and Takashi Takeda 1989. Properties and application of laminated-veneer lumber posts with hollow cores III -Shearing properties of wall frameworks made of laminated- veneer lumber posts with hollow cores and reinforced with plywood-Mokuzai Gakkaishi 35(11): 978-984

Norihiko Yamada et al. 1999. Estimation of drying stresses in hollowed log using finite element method I. -The linear finite element analysis of the drying stress were substituted by the thermal stress-. Mokuzai Gakkaishi 45(5): 403-408

Norihiko Yamada et al. 2001. High-Frequency and microwave heating as a pretreatment to kiln drying of hollowed-out timber. Mokuzai Gakkaishi 47(6): 501-507

Norihiko Yamada and Shogo Okumura 2002. J oints of hollow timbers with an oven-dried wood dowel. Mokuzai Gakkaishi 48(4): 296-301

The research on the future of Korean-style wooden building. 2007. The Korea Forest Research Institute.

Yeo, H. M. et al. 2007. Effect of center boring and kerf treatment on kiln-drying of larch square and round timber. Forest Products J. 57(11): 85-92 